\title{
DEVELOPMENT OF COMPANIES OPERATING LOGISTICS SERVICE CENTRES BY EMPLOYING THE RESULTS OF NETWORK RESEARCH
}

\author{
György Karmazin(1), Gergely Ulechla ${ }^{(2)}$ \\ (1) Ph.D., Assistant Professor, College of Szolnok, founder-owner, BI-KA Logisztika Kft \\ (2) Ph.D.-student, Szent Istvan University, Faculty of Economics and Social Sciences, \\ Doctoral School of Management and Business Administration, Regional Leader (Eastern- \\ Europe\& Emerging Markets), Arrow Electronics Inc., \\ E-mail: karmazin.gyorgy@,bi-ka.hu,gergely.ulechla@gmail.com
}

\begin{abstract}
Logistics centres of huge capacity and having the ability to create added value have emerged in recent decades. These centres have become network nodes between the co-operating organizations which accomplish the management of supply chains (networks) by connecting different modalities and networks with their infrastructure and informatics. The effective operation of logistics centres presented in business networks are usually managed by logistics supplier businesses (3PL/4PL). Defining the supply net as a complex network, logistics centres may be called hubs, the routes and relationships connecting the centres or - by borrowing the term used in network theory - may be called edges. Hub management provides core supply chain execution and visibility. Taking into consideration earlier results of network research we are searching for correlations between its proven principles and the growth possibilities of the centres (hubs) operated by logistics service providers. In addition, the results concerning cell networks provide further, new insights and increasing opportunities to consider the logistics systems within the field of theoretical network science. The present paper has developed as a result of the logistics supplier companies' strategic responses to the challenges of a rapidly changing environment, both on local and global level.
\end{abstract}

Keywords: business networks, corporate size, logistics service provider, hub, supply chain strategy

JEL classification: L14

\section{Introduction}

Each era has particular periods which determine what can be and what is worth for research. The concept of networks is a challenge which deserves undertaking now. As well as our biological existence, our communication and also our professional and social life depend on networks. Understanding them is not only necessary for scientists and laymen alike, but also indispensable since in one way or another we need to navigate the 21 st century. The technologies of the future, our would-be communication and our whole biological existence will depend on networks. Networks are already present in the 21 st century and we completely depend on them, are embedded in them in such a way that they have become an issue of such importance that without networks we are not able to "wonder about" the world anymore (Barabási, 2014a, based on interview).Man lives in symbiosis with nature surrounding him, although we tend to continually abuse it (environmental pollution), for which we are getting punished ever more often (natural disasters). Our personal experience shows that the longer we stay in nature, the more observations we make about the life of animals for example, the more principles we will discover that can be utilised for mankind as well. 
The same applies to our inland scientists doing research in network theory, who are able to draw conclusions from the movement of pigeons and the relationship of individual specimens of the bird species examined that can be employed in the development of human communities (Vicsek, 2014), as well as solutions supporting the trends of future technological development (e.g. experiments with drones within the frames of Alibaba, Amazon, Google and UPS companies operating in the logistics market).It is interesting to note that Google's drone testing is not allowed by the administration on the territory of the USA, so they are obliged to conduct them in (Világgazdaság, 2015). In nature the overwhelming majority of animal species live in groups just like we humans live our days in different communities.

The conclusion has almost become a commonplace today that a coherent (working) community is able to give stronger and better responses to the new challenges of a changing world than the individual. In the interest of corporate competitiveness it is inevitable to deal with this issue since "the employees also constitute vital foundations of a corporation" (Reszegi-Juhász, 2014, pp 14).However, we Hungarians are not doing very well in our work with our faith in the success of team work and our productivity. According to the results of a recent survey, only $50 \%$ of domestic employees show a higher performance when working in a team than working individually. Furthermore, the variegation of the composition of domestic team workers characteristically differs from the accepted norms in other cultures (Adó Online, 2014).

\section{Business networks}

The quasi structure of the global economy is made up by business networks (Gelei, 2008), which have developed in response to the ever-changing economic environment and as a result of their network building these companies have also gained considerable competitive edge. „A network - and so business networks as well - is a structure in which several nodes are linked to one another through several lines. In business networks these nodes are formed by the individual business units like production companies, buyers, logistics or even financial service providers. The linking lines can be interpreted as the connections between these nodes". (Gelei, $2008, p 4)$ The roots of business networks can be traced back to Japan where the keiretsu operate with the support of a major bank and clustered around a large company possessing massive supplier contacts (Fukuyama, 2007). In view of the international models and knowing the distribution of domestic companies by their size (Central Statistics Office, 2014), we can only hope that the Hungarian small and medium-size enterprises will be successful as part of globalising business networks. (Gelei, 2008) „According to the figures of the CSOon corporate added value published for 2013, in Hungary, similarly to international experience, productivity was much higher with companies in foreign ownership. In 2011, companies in Hungarian ownership produced 4,461 thousand forints added value, while the figure for companies in foreign ownership was 11,334 thousand forints. The latter figure is two and a half times bigger" (Reszegi-Juhász, 2014.p 14). This is one of the reasons why it is so important for domestically owned SMEs to find those success factors (e.g. logistics solutions based on the results of network research or strategic decisions resulting from the integration of business networks), which could significantly narrow the currently existing gap.

\section{Logistics processes in the supply chain}

In recent years or rather decades, due to the impact of increasing globalisation, competitiveness and customer needs, there has been a significant development in the logistics methods and solutions that are based on a systematic approach of material flow. 
This trend has been detectable at the production and consumption sites, the direct transport links between companies and later in the complex supply chains and networks. It also results from the fact that product life cycles have rapidly shortened in the industrialised countries in the last two decades. Because of the shorter life cycles the time spent on purchasing, production and sales has become more dominant, the part-processes have shortened and stock levels have been reduced. Logistics is an inter-sector activity, encompassing the whole supply chain from the producers and manufacturers to the end users.

Therefore, logistics must not be examined only in a narrower sense, in the context of goods transport and warehousing, where at the micro-economic level it basically determines business success, but in a wider environment where it plays a complex macro-economic role and assists a competitive industrial background. Generally speaking, the trends and objectives of logistics point towards achieving high standards in forwarding services and low costs in the transportation of goods. Transport on international or inland routes, to, from or through the hubs, ensures and effective flow of goods all over the world. This leads to the necessity of developing intelligent and smooth-passage linking corridors between industrial or logistics clusters resulting in creating stable and safe infrastructure, real-time connection, the sharing of information, reduction in the administration load, highly intelligent management and flexible services. Logistics service providers do all this in order to cope with the growing demand of end users and to provide for the consumers precise, reliable, fast, sustainable, but most importantly, more favourable transport services. In order to achieve this, co-operation and joint efforts are needed to make the most effective use of the knowledge and technology available and ensure operative implementation. Apart from these, information and communication technology also makes a significant impact on the development of the ever-growing complexity of logistics, especially by improving the visibility and efficiency of the supply chain which is well-illustrated by Figure 1 .

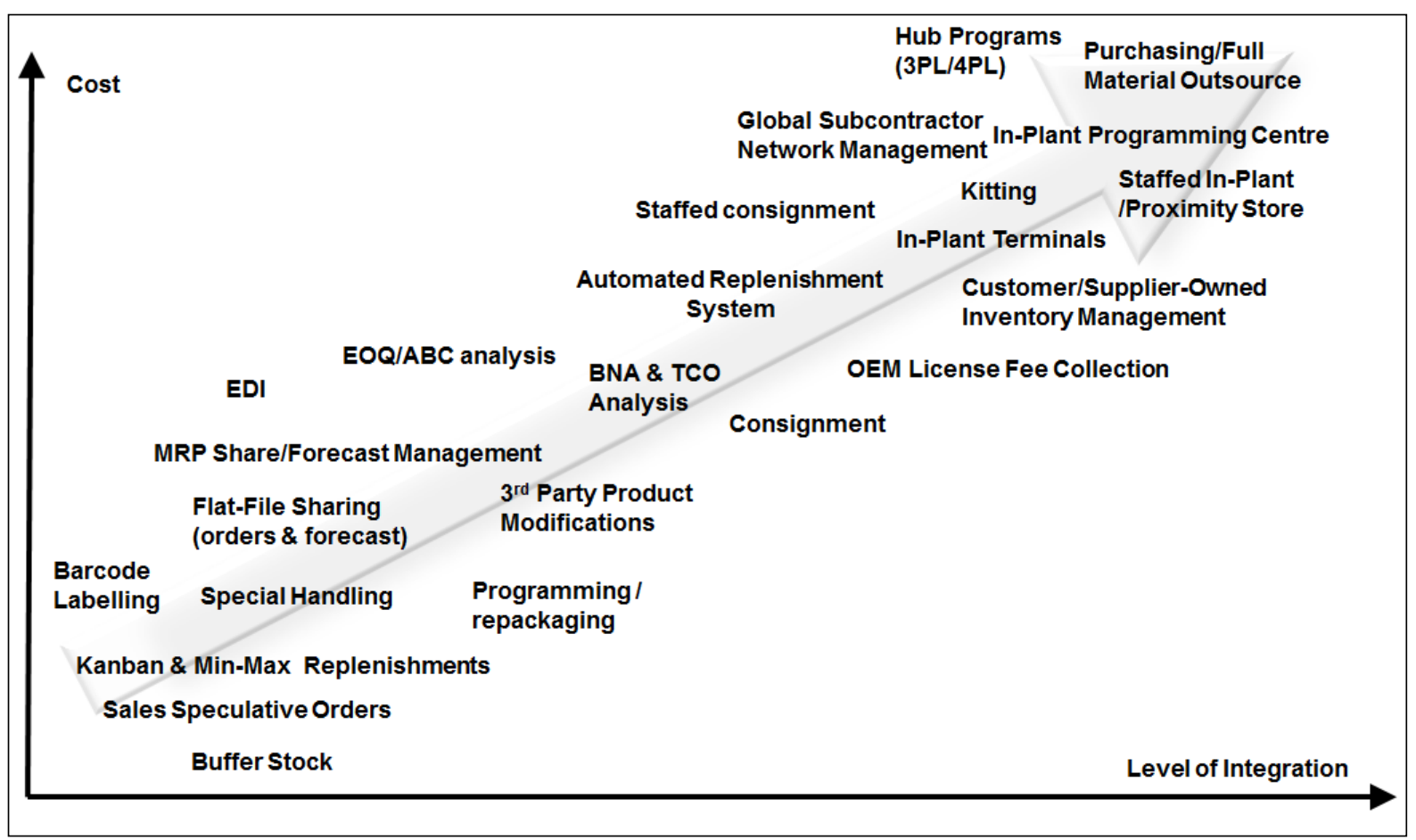

Figure 1. Logistics models in customer service

Source: author's own design, 2015 


\section{Logistics and the networks}

„Acquiring the competitive edge nowadays is gradually shifting from resource-type advantages to process-type advantages when the integration level of processes ensures the advantage in the market. The processes of logistics therefore need an integrated approach not only by themselves, but must be harmonised with other processes and also made measurable". (GyengeKozma, 2005) Naturally, this applies not only to relationships in production, but since the appearance of the logistics approach, the whole economy must be treated as a network.(Chikán, 2002 in Egri, 2014) With the emergence of the large product stopping and added value producing logistics centres, such network nodes came into being within the co-operating organisations that by connecting different transport routes and sub-branch courses with the help of infrastructure and informatics can achieve the management of supply chains (networks). The flow of information within these systems is greatly supported by the Internet, and their efficiency is significantly increased by the application of innovations and technological development. The effective operation of logistics hubs appearing business networks is normally ensured by logistics service providers (3PL/4PL) that in their strategic planning also favour the network arrangement forms.(Duleba, 2009)By interpreting supply nets as a complex network, logistics hubs can be considered as nodes and the connecting paths, borrowing the term used in network theory, can be called edges. If we accept the claims of Barabási that „,behind the existence of complex networks there must be some laws" (Barabási, 2013, p 82.), we need to find the correlations between the laws already proven by him and the growth potential of the hubs operated by service providers integrated in logistics systems. Leaving behind the description of static, randomly constructed networks, let us turn our attention to the examination the results of the dynamically growing, scale-independent networks.

\section{Growth of network points}

Barabási's first conclusion stipulates the principle of "linkage on the basis of popularity" accepting the fact that we are more likely to choose the node which has twice as many links as another one.Due to the continually increasing, dynamic, scale-independent networks and the popularity linkage principle, "a few central points with multiple links come into being". (Barabási, 2013,p99) This can as well be called the second conclusion the consequence of which is that „with the growth of the network the earlier points have more time for acquiring new linksthan the ones coming later" (Barabási, 2013, p 99). We may consider it the advantage of ,joining in time", which thanks to the effects of the two rules described above can significantly contribute to the growth of a central point. Returning to the world of business, Reszegi \& Juhász point out that "in principle, if the market functions flawlessly, the differences between individual companies within one sector tend to level off. This can be the result of several, sometimes contradictory processes" (2014, p 16.). However, markets generally do not work in an optimal way consequently ,resources tend to flow towards the more productive ones, they employ more means and labour than previously and so their weight increases". (Reszegi-Juhász, 2014, p 16) In his research into the behaviour of stress proteins, Csermely has concluded that „,stress proteins stabilise the network of the cell of which they form a part” $(2004, \mathrm{p} 7)$.

During his research he discovered the formation of nodes, their importance and necessity, but also found that with the removal of these modes the complex networks generally fall apart.

His main interest concerned the observation of the habits of stress proteins and he noticed that „when I block the stress protein, the lack of stability causes a difficult situation, but it does not mean death by itself". (Csermely, 2004, p 7) During his observation he realised that the bonding 
in the cell network ,is stabilised by the elements which are weakly linked to one another. It is neither the element nor the number of interactions which are important here, but the strength of their interactions" (Csermely, 2004, p 7).

But what will happen to the latecomers who because of their age or idea enter later into an already functioning business network? By examining the process that separates the winners from the losers, we can see that the competition manifested in complex systems gives a chance to the better adapting companies (in our case points) to gain advantage over their competitors (possibly the older points) due to their "fitness".(Barabási, 2014b)We can call this the rule of competence which basically "does not eliminate the mechanisms regulating growth and popularity linkage". (Barabási, 2013, p 109)Returning again to the business relationships, the results of the research by Reszegi-Juhász show that „those lagging behind show little or no affinity to accommodate positive impulses (affecting competitiveness, productivity, etc. author's comments). Consequently, there is a chance that the weak will remain weak in the future as well". (2014, p 17) Returning to nature we can see that most living systems are capable of staying alive even in very diverse environmental conditions (Barabási, 2013), whereas in the systems operated by man it often happens that due to minor malfunctions the whole man-made structure becomes unserviceable. Therefore, the study of robustness (error tolerance) may yield important conclusions regarding operability since the operability of every system ,is guaranteed by a complex, closely related network". (Barabási, 2013, p 125) Applying the above rules, Barabási and his team are able to day to undertake to determine of a dynamic, scale-independent network whether it follows ,the rich will get richer" or "the winner takes all” scheme.

Let us see what parallels we can draw between the above rules and the strategy choices and growth potentials of logistics service providers. „In the past, strategic decisions were typically considered to apply for „long term” and „,for several years” type of decisions. By now, however, "long term" as a calendar term has lost its meaning in several branches of business. Business and planning cycles are continually getting shorter so it does not seem practical to treat strategic decisions as long-term ones, without the required flexibility. Instead, we should concentrate on recognising the decisions that go beyond their own areas or the economic cycle in question or even the given economic framework." (Gyenge et al, 2013)

\section{Parallels and recommendations}

The unbroken growth in global goods turnover and the projections and undiminished popularity of e-commerce - only in China an annual 20 percent growth has been forecast in this area until 2019 -(Forrester, 2015) continually ensures the dynamic development of logistics networks interweaving the whole world, so the above conclusions can be applied to logistics systems as well.

Table 1 summarises the results and general conclusions of network theory and the recommendations concerning the logistics service providers operating logistics centres and committed to growth and activities supporting business strategies.

The basis for these recommendations is provided by the results of an empirical, primary and representative research conducted among inland logistics service providers (Karmazin, 2014), and the author's practical experience gained with his own logistics company as well as the conclusions drawn from the results of national and international research and scientific publications utilised in writing the present paper. 
Table 1.Development of network points and the correlations of support activities used in implementing the strategies of logistics service providers

\begin{tabular}{|c|l|}
\hline $\begin{array}{c}\text { Development of a } \\
\text { network point }\end{array}$ & \multicolumn{1}{|c|}{$\begin{array}{c}\text { Support activities implementing the strategies of logistics } \\
\text { service providers }\end{array}$} \\
\hline popularity & $\begin{array}{l}\text { effective PR and marketing activities, commitment to high } \\
\text { professional standards, openness to the environment, raising the } \\
\text { level of trust in business relations, opening up to new sectors, } \\
\text { establishing new contacts with Internet support }\end{array}$ \\
\hline $\begin{array}{c}\text { central point } \\
\text { (measure) }\end{array}$ & $\begin{array}{l}\text { acceptance of a growth strategy within the company } \\
\text { organisation, forming co-operation seven with rival companies, } \\
\text { strategic acquisitions }\end{array}$ \\
\hline joining in time & $\begin{array}{l}\text { flexibility, inductive behaviour, entering new markets, } \\
\text { introduction and implementation of new services and } \\
\text { technologies }\end{array}$ \\
\hline competence & $\begin{array}{l}\text { improving ability for change, sector-specific IT development, } \\
\text { continuous training, openness to new phenomena }\end{array}$ \\
\hline robustness & $\begin{array}{l}\text { high standard application of ISO, implanting correcting } \\
\text { mechanism into business processes (PDCA cycle),involvement, } \\
\text { delegating, authorising decisions at lower levels, wide service } \\
\text { and customer (industry sector) portfolio }\end{array}$ \\
\hline strength of weak links & $\begin{array}{l}\text { accession to associations and interest groups, signing co- } \\
\text { operation agreements with government agencies, law- } \\
\text { enforcement bodies, participation in non-sectoral events, } \\
\text { organisation and sponsorship of economic events, non-profit } \\
\text { activities and support, belonging to clusters }\end{array}$ \\
\hline
\end{tabular}

Source: author's own design, 2015

\section{Summary}

We can find a number of inland publications based on the results of network research even concerning college students as a target group. (Cserjés-Záborszky, 2011)However, there have been no publications with relevant conclusions written by researchers or experts of business life regarding logistics service providers taking part in business networks. Therefore, the present paper is partly filling a niche.

On the other hand, as an edification of the above conclusions and recommendation - and quoting and complementing the words of Egri - we can state that ,network theory is capable of becoming a useful toolbar for logistics, which in international logistics, production logistics and the processes of the global economy can make optimal arrangements more recognisable and by shortening the links can function as an intensifier for economic efficiency." (2014,p 28)Furthermore, these new impacts will play an important role in forming the strategy of inland logistics service providers as well.

Research investigating logistics service providers on the national (Karmazin, 2014) and international (Kotonen, 2012) scene, have tackled the issues of strategy choice and potential development of the actors in the logistics market from different aspects. However, the above paper with its network theory approach and the resulting conclusions may offer a new way of thinking for the decision makers at inland logistics service providers operating logistics centres in Hungary. 


\section{References}

1. Adó online (2014): Nem csapatjátékos a magyar. http://ado.hu/rovatok/munkaugyek/nem-csapatjatekos-a-magyar (letöltés dátuma: 2014.12.04.)

2. Albert, R. - Jeong, H. - Barabási, L. (2000): Attack and error tolerance of complex networks. Nature 406, 378-382.o. http://dx.doi.org/10.1038/35019019

3. Barabási, A. L. (2013): Behálózva. A hálózatok új tudománya. Helikon Kiadó, Budapest. $82,99,109,125$. o.

4. Barabási, A. L. (2014a):http://www.mediaklikk.hu/2014/12/06/nezze-ujra-primaprimissima-2014/, (letöltés dátuma: 2014.12.07.)

5. Barabási, A. L. (2014b): Behálózva. Üzleti Gondolkodók Klubján elhangzott előadás, Budapest, 2014. október 8.

6. Cserjés Á. - Záborszky Á.(2011): Skálafüggetlen eloszlás és hallgatói élet a közösségi hálón. In: Madaras L. - Subecz Z. (szerk.): Economica, IV. Új különszám, 2011, 56-63. oldal

7. Csermely P. (2004): A rejtett hálózatok ereje (Hogyan stabilizálják a világot a gyenge kapcsolatok?). Vince Kiadó, 2004, 7. oldal

8. Duleba, SZ. (2009): Az AHP módszer egy lehetséges alkalmazása trendek előrejelzésére. Szigma. XL évfolyam, 3-4 szám, 41-43. o.

9. Egri, I. (2014): Hálózatok és logisztika. Duleba Szabolcs (szerk.): Logisztikai évkönyv 2015, Magyar Logisztikai Egyesület, Budapest, 27-33. o.

10. Forrester (2015): China Online Retail Forecast, 2014 To 2019. Embrace The Mobile Sales Momentum In China, 2015.02.04.

11. https://www.forrester.com/China+Online+Retail+Forecast+2014+To+2019/fulltext/-/ERES118544 (letöltés dátuma: 2015.02.09.)

12. Fukuyama, F. (2007): Bizalom - A társadalmi erények és a jólét megteremtése. Európa Könyvkiadó, Budapest, 17-513. o.

13. Gelei, A. (2008): Hálózat - a globális gazdaság kvázi szervezete. 95. sz. Mühelytanulmány, Budapesti Corvinus Egyetem Vállalatgazdaságtan Intézet, 2008. június

14. Gyenge, B. - Buresch, J. - Kozma, T. (2013): How to Measure the Efficiency of Management Strategy in Organisational Structure. In: Bylok F. at al. (szerk.): Human Capital and Corporate Responsibility, Politechniki Czestochowskiej, Lengyelország Czestochowa, pp. 60-72.

15. Gyenge B. - Kozma T. (2005): A logisztika és a minőség kapcsolata. In: Szücsné Szaniszló Zs (szerk.) Nyertesek és vesztesek - az EU-csatlakozás 1,5 éves tapasztalatai. V. Regionális Tanácsadási Konferencia, Miskolci Egyetem Gazdaságtudományi Kar, Miskolc, 3. o.

16. Karmazin, GY. (2014): A logisztikai szolgáltató vállalatok gazdálkodási sikertényezőinek és stratégia-választásának hatása a vállalat eredményességére, doktori $(\mathrm{PhD})$ értekezés

17. http://www.doktori.hu/index.php?menuid=193\&vid=12695 (letöltés dátuma: 2014.12.05.)

18. Kotonen, U., Lahtinen, H., Savonen, M-L, suomäki, A. \& Tuominen, U. (2012): Process and methods of competence management and development. In Ulla Kotonen, Anu Suomäki (eds.): competence development of logistics centers, Lahti University of Applied Sciences, 22-28.o.

19. Központi Statisztikai Hivatal (KSH) (2014): Statisztikai Tükör 2014/30. 
20. Központi Statisztikai Hivatal (KSH) (2013): A külföldi irányítású, nem pénzügyi leányvállalatok hozzáadott értékének nagysága és aránya nemzetgazdasági ág és a végső tulajdonos székhelye szerint (2008-), http://www.ksh.hu/docs/hun/xstadat/xstadat_eves/i_qtd004c.html, letöltve: 2015. február 17.

21. Randstad (2014): Randstad Workmonitor wave 3, 2014 incl. quarterly mobility, job change and job satisfaction. Global report, Group communications, Randstad Holding nv, September 2014

22. Reszegi L. - Juhász P. (2014): A vállalati teljesítmény nyomában. Alinea Kiadó, Budapest, 14-17. oldal

23. Vicsek, T. (2014): Why do we live in hierarchies? Multi-level hierarchical networks of connections in life. XXII. MLBKT Kongresszuson elhangzott előadás, Siófok, 2014. november 13 .

24. Világgazdaság (2015): Drónokat vetne be az Alibaba. 2015. február 6., 47. évfolyam, 25. (11534) szám, 9. oldal 